\title{
Assessment of Freeze Injury of Grapevine Green Tissues in Response to Cultivars and a Cryoprotectant Product
}

\author{
Michela Centinari ${ }^{1}$ and Maria S. Smith \\ Department of Plant Science, Pennsylvania State University, Tyson Building, \\ University Park, PA 16802
}

\author{
Jason P. Londo \\ United States Department of Agriculture-Agriculture Research Service, \\ Grape Genetics Research Unit, 630 West North Street, Geneva, NY 14456
}

Additional index words. frost resistance, KDL, osmotic potential, phenological development, Vitis ssp.

\begin{abstract}
Spring frosts and subsequent crop losses threaten the economic sustainability of fruit crop producers all over the world. This study used a controlled-freezing technique to impose a post-budburst freezing stress to grapevine shoots forced from one-node cuttings ['Albariño', 'Cabernet Franc', 'Cabernet Sauvignon', and 'Pinot Grigio' (Vitis vinifera)] and whole plants ['Noiret' (Vitis hybrid)]. Our goal was to investigate the incidence of freeze injury among cultivars, stage of phenological development, and a potassium salt-based fertilizer (KDL) with potential cryoprotectant activity. Among the $V$. vinifera cultivars, the incidence of mortality of shoots exposed to $-3.5{ }^{\circ} \mathrm{C}$ was highest for 'Albariño' (71\%) and lowest for 'Cabernet Sauvignon' (51\%). Cuttings sprayed with KDL 24 hours before cold temperature exposure exhibited 16\% lower shoot mortality and lower osmotic potential $\left(\Psi_{\mathrm{s}}\right)(-0.92 \mathrm{MPa})$ than the unsprayed cuttings ( $-0.77 \mathrm{MPa}$ ). However, application of KDL did not impact shoot mortality for whole 'Noiret' vines. Mortality for 'Noiret' shoots greatly increased with the advancement of phenological development, ranging from $10 \%$ in wooly buds to $78 \%$ in shoots $\approx 10$-cm long. The practical significance of KDL remains questionable; cultivar selection still appears to be a more reliable method for avoiding spring frost, by planting late bursting cultivars in more frost-prone areas.
\end{abstract}

Crop losses to freeze injury represent a major economic threat to horticultural production. In the United States, economic losses related to cold-temperature injury are greater than to any other weather-related phenomenon (Snyder and de Melo-Abreu, 2005). Freeze injuries to perennial fruit crops can occur before dormancy in the fall, during the dormant season, and in the spring during and after budburst (Rodrigo, 2000). To date, studies on plant acclimation to low temperatures have mostly focused on tolerance of dormant tissues to low winter temperatures, a major environmental constraint on the distribution of fruit crops in cold-climate regions (Wolf, 2008). Freeze injury to vulnerable,

Received for publication 19 Apr. 2016. Accepted for publication 12 May 2016.

We thank Donald Smith and Marine Galanopoulo for field and laboratory assistance. We also thank Rich Marini and Rob Crassweller for the critical reading of the manuscript.

Mention of a trademark, proprietary product, or vendor does not constitute a guarantee or warranty of the product by the U.S. Dept. of Agriculture and does not imply its approval to the exclusion of other products or vendors that also may be suitable. ${ }^{1}$ Corresponding author. E-mail: mzc22@psu.edu. green, and actively growing plant tissues can also negatively impact production of many fruit crops all over the world (Barranco et al., 2005; Kappel, 2010; Molitor et al., 2013; Rowland et al., 2013). For example, in 2007, widespread spring frosts in the eastern and midwestern United States resulted to estimated \$2 billion in crop losses (Warmund et al., 2008).

Factors affecting the extent of freeze injury in young and developing plant tissues include cultivar, dew point and surface moisture, probability of an ice nucleation event, prefrost environmental conditions, and stage of development, with budburst considered the onset of the most susceptible period (Trought et al., 1999). To avoid or reduce the risk of a post-budburst frost-damaging event, growers preferentially plant cultivars with delayed phenological development in more frost-prone areas. However, cultivar differences in frost resistance appeared to be related to factors other than bud phenology. Small but consistent differences in frost resistance of buds at the same growth stage were reported between 'Concord', 'Vidal Blanc', and 'Baco Noir' vines (Johnson and Howell, 1981a). Severity of freeze injury was affected by cultivar in olive (Barranco et al.,
2005), almond (Imani et al., 2011), blueberry (Rowland et al., 2013), and sweet cherry (Kappel, 2010) trees.

In addition to cultivar selection, growers can adopt other frost protection methods to reduce the risk of spring freeze injury. Frost protection methods have been developed to either modify microclimate conditions in the orchard or vineyard (i.e., wind machines, heaters, etc.), inhibit formation of ice in plant tissues (i.e., over-vine/tree sprinkling irrigation), or decrease the probability or severity of frost damaging events (i.e., site selection, application of chemical compounds to delay budburst, and cultural practices) (Evans, 2000). Installation and operation of frost protection methods may require large investments and growers managing small size orchards or vineyards cannot justify the costs involved. Therefore, there is an extensive need for low-cost methods for protecting crops against spring freeze injury.

A potentially affordable approach to decrease freeze injury to young plant tissues is through exogenous application of surface or systemic cryoprotectant products. Surface cryoprotectants are thought to cover green tissues with a physical barrier, which may prevent the formation of ice crystals inside the plant (Fuller et al., 2003). Systemic cryoprotectants are used to mimic natural frost tolerance or avoidance mechanisms (Wilson, 2001) by stabilizing proteins and membrane functions (Nuccio et al., 1998) and/or by cellular changes in $\Psi_{\mathrm{s}}$. Indeed, a decrease in $\Psi_{\mathrm{s}}$ resulting from increased intracellular solute concentration may lower the freezing point of the cytoplasm and reduce cell dehydration caused by extracellular freezing (Sakai and Larcher, 1987).

Agrochemical companies have promoted the application of chemical compounds for frost protection, and many products have been screened over the last 30 years for cryoprotectant activity with inconsistent results. Foliar applications of antitranspiring compounds (surface cryoprotectants) were ineffective to decrease post-budburst freeze injury in peach (Matta et al., 1987), young citrus (Burns, 1973), and tomato and pepper (Perry et al., 1992). On the contrary, the application of a hydrophobic particle film (CM-96-018) led to a decrease in freeze injury in potatoes, grapevine, and citrus plants (Fuller et al., 2003).

Foliar applications of systemic cryoprotectants (e.g., glycine betaine, ethylene glycol, and BRIJ 35) increased freeze resistance in grapevines (Himelrick et al., 1991) and in Arabidopsis thaliana (Xing and Rajashekar, 2001). However, another commercial product advertised as a systemic cryoprotectant (e.g., frostgard) was ineffective in decreasing freezing temperature in 'Pinot Noir' vines (Gardea et al., 1993) or 'Arking' strawberry plants (Anderson and Whitworth, 1993). Similarly, several cryoprotectants (e.g., frostgard, frostfree, and KDL) were ineffective in reducing flower freeze damage of 'Honeoye' strawberry plants (Warmund and English, 1994). 
A foliar macronutrient, Agro-K's Potassium Dextrose-Lac ${ }^{\circledR}$ (KDL; 0N-0P-24K) (Agro-K Corporation, Minneapolis, MN) has received increased attention for its potential cryoprotectant activity. Foliar application of KDL within $36 \mathrm{~h}$ of a predicted frost event is advertised to protect green tissues of plants against freeze injury. Although the mechanism of action is not clear, the product is attractive to growers due to its low cost and several positive testimonials (Agro-K Corporation, 2016). The product label indicates that KDL derives from potassium carbonate $\left(\mathrm{K}_{2} \mathrm{CO}_{3}\right)$ and Ascophyllum nodosum. Therefore, a hypothetical mechanism of action may include increased frost resistance due to $A$. nodosum extract and/or to an increase of potassium $(\mathrm{K})$ concentration. Potassium is one of the major osmotic solutes of plant cells, therefore its accumulation in the cell could increase tolerance to cellular freezing (Keller, 2010). An extract of the brown seaweed $A$. nodosum increased tolerance in A. thaliana to cold temperatures $\left(-5.5^{\circ} \mathrm{C}\right)$ when the plants were irrigated $48 \mathrm{~h}$ before the freezing treatment (Rayirath et al., 2009).

In this study, we used four grapevine cultivars $(V$. vinifera $\mathrm{L}$.) to test the hypothesis that post-budburst freeze injury varies between genotypes and in response to application of KDL. To assess if the mechanism of action of the KDL was related to an increase of intracellular solute concentration, $\Psi_{\mathrm{s}}$ was measured. A second experiment was conducted on 'Noiret' (Vitis hybrid) vines to assess the impact of KDL on post-budburst freeze injury on a hybrid grapevine cultivar and to explore the relationship between shoot mortality induced by freezing temperature and stage of phenological development.

\section{Materials and Methods}

A controlled-freezing method was used to impose freezing stress on grapevine shoots forced from one-node cuttings of four cultivars ( $V$. vinifera L.) and on container-grown 'Noiret' (Vitis hybrid) vines.

Controlled-freezing experiment on cuttings. Single-bud cane cuttings of 'Albariño', 'Cabernet Franc', 'Cabernet Sauvignon', and 'Pinot Grigio' vines (Vitis vinifera L.) were selected for this study. The plant material was collected from a vineyard located at the Fruit Research and Extension Center of the Pennsylvania State University in Biglerville, PA. The vineyard was established in 2008 as part of the research project NE-1020 "multi-state evaluation of wine grape cultivars and clones." 'Cabernet Franc', 'Cabernet Sauvignon', and 'Pinot Grigio' are grapevine cultivars widely grown in the eastern United States (Wolf, 2008). 'Albariño' is a white grapevine cultivar widely grown in the Galicia region in the northwest of Spain, which has been gaining popularity among growers and wine consumers in the eastern United States. The four cultivars were planted in a randomized complete block design with six blocks, each consisting of four vines per cultivar. The vines were grafted on Millardet et de Grasset 101-14 (101-14 Mgt) rootstock and trained to bilateral flat cane system with vertical shoot positioning.

The cuttings were obtained from nodes three to seven of 1-year-old canes collected from the six blocks during the dormant season (1 Feb. 2015). The canes were brought to the laboratory and cut into 6- to 8-cm-long sections with a single node and bud. Singlebud cuttings were placed in vented plastic bags containing damp toweling and stored in a refrigerator at $\approx 4{ }^{\circ} \mathrm{C}$ until processing (Anderson and Whitworth, 1993).

A temperature-controlled programmable freezer (VersaTenn; Tenney Engineering, NJ) was used for this experiment. Due to the limited space in the freezer cabinet $(0.28 \mathrm{~m}$ wide $\times 0.41 \mathrm{~m}$ long $\times 0.40 \mathrm{~m}$ high $)$ up to 40 cuttings could be used in each freezing test. Starting 1 Mar. 2015, 30 cuttings of each cultivar were removed every $4 \mathrm{~d}$ from the refrigerator and forced in a growth chamber (temperature $21^{\circ} \mathrm{C}$ day $/ 18{ }^{\circ} \mathrm{C}$ night; $12 \mathrm{~h}$ daylength at a photon flux density of $150 \mu \mathrm{mol} \cdot \mathrm{m}^{-2} \cdot \mathrm{s}^{-1}$ of photosynthetic active radiation). The single-bud cuttings were placed in plastic cups filled with water and randomly assigned to the treatments: 1) control (C): unsprayed cuttings, 2) KDL24: cuttings sprayed with KDL 24 h before lowtemperature exposure, and 3) KDL48: cuttings sprayed with KDL 48 h before lowtemperature exposure. Cane cuttings did not produce roots during the time period of the study. An average of $\approx 10 \%$ budburst failure was recorded.

Time intervals between KDL application and low-temperature exposure were included to evaluate for potential increase in KDL effectiveness over time, as suggested for other cryoprotectant products (Wilson, 2001). Manufacturer recommendation was followed for KDL application (Agro-K Corporation, 2014). KDL was applied as aqueous solution at a rate of $1 \%(\mathrm{v} / \mathrm{v})$ by spray bottle until runoff to avoid phytotoxicity (Wilson, 2001). Spray mixture was agitated before spraying.

Because freezes were controlled, we evaluated freeze injury at a specific stage of development (Rowland et al., 2013), defined as stage nine of the modified Eichhorn and Lorenz (E-L) system of grapevine development (Coombe, 1995). The grapevine shoots selected for the freezing test were $2-$ to $3-\mathrm{cm}$ long with two leaves unfolded. Since budburst in the four cultivars occurred over a range of days, it was not possible to test every cultivar at the same time.

A total of 15 freezing tests were performed. In each freezing test, the samples were placed in a completely randomized arrangement in the freezer cabinet. The base of the cutting was placed into moist floral foam (Johnson and Howell, 1981b) on a plastic tray. Before positioning the tray in the freezer, the young shoots were sprayed with distilled water to induce external ice nucleation formation (Pearce, 2001). In laboratory tests of freezing resistance, the absence of surface moisture could facilitate artifactual supercooling, resulting in plants surviving cold temperature exposure undamaged. For each CV tested, the three FP treatments were loaded on the same run ( $n=5$ or 6 cuttings for each $\mathrm{CV} \times \mathrm{FP}$ ); a total of five to six freezing tests were conducted for each $\mathrm{CV} \times \mathrm{FP}$ combination ( $\mathrm{n}=30$ cuttings).

The temperature in the freezer was lowered from 16 to $-3.5{ }^{\circ} \mathrm{C}$ at a rate of $\approx 2{ }^{\circ} \mathrm{C}$ per $\mathrm{h}$ before rewarming to temperatures above freezing at the same rate. The air temperature took $\approx 10 \mathrm{~h}$ to reach $-3.5{ }^{\circ} \mathrm{C}$ and the target temperature was held for $30 \mathrm{~min}$. The temperature of $-3.5{ }^{\circ} \mathrm{C}$ was determined based on data of critical temperature for developing grapevine buds (Fuller and Telli, 1999; Johnson and Howell, 1981b). Air temperature in the freezer cabinet was monitored by wireless temperature data loggers (iButton Fob, Model DS9093F; Embedded Data Systems, Lawrenceburg, KY) placed at four points across the cabinet at the shoot height. Air temperature was recorded every 2 min to monitor variation in temperature in the freezer cabinet and among freezing tests

At the end of the freezing test, the samples were transported to the growth room and $2 \mathrm{~d}$ later, shoots were evaluated for freeze injury by visual assessment. Injury on the young shoots (leaves and apex) was assessed on a five-point scale as in Fuller et al. (2003), where $0=$ no visible injury, $1=$ slight, $2=$ moderate, $3=$ severe, and $4=$ complete kill.

Osmotic potential measurement. In Mar. 2015, buds were forced from stored 'Albariño', 'Cabernet Franc', 'Cabernet Sauvignon', and 'Pinot Grigio' cuttings in the growth chamber under the same growing conditions of the cuttings used in the freezing test. The cuttings were randomly assigned to treatments C, KDL24, and KDL48. KDL was applied following the same protocol used in the freezing test. When shoots reached stage nine of phenological development (modified E-L system), leaf tissues were sampled, immediately frozen in sealed test tubes, and stored at $-20{ }^{\circ} \mathrm{C}$ until $\Psi_{\mathrm{s}}$ analysis. A total of 20 cuttings for each $\mathrm{CV} \times \mathrm{FP}$ combination were selected for $\Psi_{\mathrm{s}}$ measurements. Thereafter, leaf tissues were thawed and $10 \mu \mathrm{L}$ of expressed leaf sap was used to measure the osmolality using a 5500 vapor pressure osmometer (Wescor Inc., Logan, UT). Solutions of sodium chloride $(\mathrm{NaCl})$ were used for the calibration of the osmometer. As reported by Turner (1981), potential mixing of symplast and apoplast solutions may cause an overestimation of $\Psi_{\mathrm{s}}$. Osmotic pressure $(\pi, \mathrm{Pa})$ was calculated using the Van't Hoff equation and expressed as $\Psi_{\mathrm{s}}(\mathrm{MPa})$ :

$$
\pi=m \times R \times T
$$

where $m$ is the osmolality $\left(\mathrm{mol} \cdot \mathrm{kg}^{-1}\right), R$ is the universal gas constant $\left(\mathrm{J} \cdot \mathrm{mol}^{-1} \cdot \mathrm{K}^{-1}\right)$, and $T$ is the thermodynamic temperature $(\mathrm{K})$.

Controlled-freezing experiment on whole vines. Sixteen 3-year-old 'Noiret' (Vitis hybrid) vines grown in 19-L pots were used for this experiment. The vines were pruned to 
two canes of $12 \pm 2$ buds each in Nov. 2014 and stored in a cooler at $3{ }^{\circ} \mathrm{C}$ until Apr. 2015. The vines were transferred outdoors at The Pennsylvania State University Russell E. Larson Agricultural Research Center at Rock Springs, PA, and arranged in two rows with the canes horizontally tied to a trellis wire to promote uniform budburst. Half of the vines $(\mathrm{n}=8)$ were randomly assigned to the $\mathrm{C}$ treatment, and the other half to the KDL24 treatment. Vines were visually evaluated for budburst (stage four, modified E-L system) twice a week.

A freezing test was performed when $70 \%$ of the buds per vine reached or passed stage four of development (modified E-L system). Shoots and buds of the vines assigned to the KDL24 treatment were sprayed with an aqueous solution of KDL 1\% (v/v) $24 \mathrm{~h}$ before low-temperature exposure. The vines were transported to Cornell University (Ithaca, NY) where a customized programmable freezer (Mitsubishi Reefer CPE-15; Mitsubishi Heavy Industries, Tokyo, Japan) was available. Three chambers separated by insulated doors and walls had been previously installed inside the freezer.

Phenological stage of each bud/shoot was recorded and vines were sprayed with water, again to induce extracellular ice nucleation, immediately before positioning them in the freezer. The vines were placed in a completely randomized arrangement in the middle freezer chamber. The middle chamber measured $2.29 \mathrm{~m} \times 3.35 \mathrm{~m}$ with a $0.91-\mathrm{m}$ door arc. Prior testing of the freezer with potted vines suggested that $-4{ }^{\circ} \mathrm{C}$ was the minimum temperature needed to induce moderate tissue injury in 'Noiret'. Temperature was set to $6^{\circ} \mathrm{C}$ the night before freezing to stabilize temperatures inside the chamber. Once the vines were placed inside the chamber, temperature was held constant for $1 \mathrm{~h}$ before decreasing by $1.5{ }^{\circ} \mathrm{C}$ per hour to a minimum temperature of $-4{ }^{\circ} \mathrm{C}$. The minimum temperature was held for $1 \mathrm{~h}$ before increasing $2{ }^{\circ} \mathrm{C}$ per hour until reaching $7{ }^{\circ} \mathrm{C}$. Three temperature data loggers were used to record air temperature every 2 min at different locations in the freezer chamber. The temperature data loggers were distributed evenly and diagonally across the interior freezer space.

After the freezing test was completed, the vines were transported to The Pennsylvania State University Agricultural Research Center at Rock Springs, PA, and visually evaluated for freeze injury $48 \mathrm{~h}$ following the freezing test. Injury on the young shoots was assessed on a five-point scale, similar to the cuttings experiment.

Statistical analyses. Statistical analyses were carried out using the SAS software package (SAS Institute, Cary, NC). The experimental design was a completely randomized design for both experiments. In the cuttings' experiment, two-way analysis of variance (ANOVA) was used to examine $\mathrm{CV}$ and FP material treatments and their interaction effect on incidence of shoot mortality and $\Psi_{\mathrm{s}}$. Because the interaction was not significant, the main effects of CV and FP were compared using the Tukey-Kramer adjustment for multiple comparisons. In the whole vines' experiment, one-way ANOVA was used to examine KDL24 effect on shoot mortality. In both experiments, binomial distributed data (i.e., shoot mortality) were analyzed using Proc GLMMIX employing the logit distribution option. Osmotic potential data were analyzed using Proc MIXED. Regression analysis was used to explore relationship between stages of phenological development and shoot mortality for Noiret $\mathrm{C}$ vines.

\section{Results}

Controlled-freezing experiment on cuttings. The temperature profile used injured the young shoots. No variation in air temperature among freezing tests was recorded. Of the 360 shoots evaluated for injury, only three were assigned to class 2 , moderate injury. All the other shoots were scored either as $0=$ no visible injury, or $4=$ complete kill. Likewise, a clear bimodal distribution of score data, i.e., either no injury or complete injury, was observed after a freezing test on whole grapevine, potato, and lemon plants (Fuller et al., 2003). Therefore, only shoots assigned to class 0 and 4 were used for data analyses. Freeze injury was evaluated as shoot mortality, expressed as the percentage of dead shoots over the total number of shoots tested.

The CV factor had the greatest impact on shoot mortality (Table 1). Shoot mortality for 'Albariño' was $19 \%(P=0.035), 20 \%(P=$ $0.028)$, and $17 \%(P=0.077)$ higher as compared with that for 'Cabernet Franc', 'Cabernet Sauvignon', and 'Pinot Grigio', respectively. Difference in shoot mortality due to FP treatment was significant at $P_{\mathrm{FP}}=$ 0.075 level. Shoot mortality of cuttings sprayed with KDL $24 \mathrm{~h}$ before lowtemperature exposure was $16 \%$ lower than that of unsprayed cuttings $(P=0.099)$. Shoot mortality for $\mathrm{C}$ cuttings and those sprayed with KDL $48 \mathrm{~h}$ before low-temperature exposure was similar $(P=0.996)$. We elected to use a more liberal critical value to test our hypotheses (probability value of $10 \%$ instead of $5 \%$ ) (Table 1). As suggested by Marini (1999), we presented the exact $P$ value to

allow readers to develop their own interpretation of the data to decide, for example, if $16 \%$ lower shoot mortality would be economically important or not.

Cultivar and FP significantly influenced $\Psi_{\mathrm{S}}$ (Table 2). Osmotic potential ranged from an average of $-0.74 \mathrm{MPa}$ for 'Albariño' to $-0.98 \mathrm{MPa}$ for 'Pinot Grigio'. Osmotic potential was lower for shoots treated with KDL24 $(P<0.001)$ and KDL48 $(P=0.002)$ than for $\mathrm{C}$ shoots.

Controlled-freezing experiment on whole vines. Freeze injury scores on 'Noiret' shoots revealed a clear bimodal distribution, i.e., the shoots were either not injured or completely injured similar to previous work (Fuller et al., 2003). Shoot mortality was unaffected by KDL application $(P=0.316)$ (Fig. 1). A similar number of shoots in the C $(50 \%)$ and KDL24 (56\%) 'Noiret' vines died after the freezing test.

Data of $\mathrm{C}$ vines were used to explore the relationship between freeze injury and phenological development. Our data showed that the incident of shoot mortality was positively related to the stage of phenological development $\left(R^{2}=0.81, P<0.001\right)$ (Fig. 2). Shoot mortality increased from $10 \%$ at stage three "wooly bud" to $78 \%$ at stage 12 "shoots $\approx 10$-cm long, five leaves separated, and inflorescence clear."

\section{Discussion}

Our study used controlled-freezing tests on single-bud cane cuttings and whole plants to assess freeze injury in grapevine shoots in the post-budburst stages. Incidence of shoot mortality in response to freezing stress was evaluated in relation to cultivar (controlledfreezing experiment on cuttings) and stage of phenological development (controlledfreezing experiment on whole vines). The impact on shoot mortality of a commercial product (KDL) with potential cryoprotectant properties was also evaluated.

Estimates of frost resistance under natural conditions are challenging and complicated. Frost events are unpredictable in nature and limited detailed information is available on minimum temperatures reached during frost events as well as their duration (Neuner et al., 1997). Hence, studies on frost resistance are

Table 1. Impact of cultivar (CV) and frost protection (FP) treatments on incidence of shoot mortality (\%).

\begin{tabular}{|c|c|c|c|c|c|}
\hline \multirow[b]{3}{*}{ FP } & \multicolumn{5}{|c|}{$\mathrm{CV}$} \\
\hline & Albariño & Cabernet Franc & Cabernet Sauvignon & Pinot Grigio & $\overline{\text { Mean }}$ \\
\hline & \multicolumn{5}{|c|}{ Shoot mortality (\%) } \\
\hline$\overline{\mathrm{C}^{\mathrm{z}}}$ & $72^{y}$ & 61 & 54 & 56 & $60 a^{x}$ \\
\hline KDL24 & 67 & 27 & 41 & 44 & $44 \mathrm{~b}$ \\
\hline KDL48 & 73 & 68 & 57 & 60 & $64 \mathrm{a}$ \\
\hline Mean & $71 \mathrm{a}$ & $52 \mathrm{~b}$ & $51 \mathrm{~b}$ & $54 \mathrm{~b}$ & \\
\hline$P$ value $\mathrm{CV}$ & 0.020 & & & & \\
\hline$P$ value FP & 0.075 & & & & \\
\hline$P$ value $\mathrm{CV} \times \mathrm{FP}$ & 0.353 & & & & \\
\hline
\end{tabular}

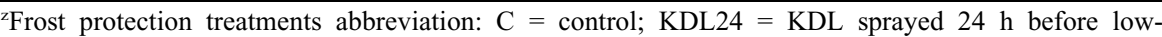
temperature exposure; KDL48 $=\mathrm{KDL}$ sprayed $48 \mathrm{~h}$ before low-temperature exposure.

${ }^{y}$ Values are percentages of 30 cuttings, except for Albariño-KDL24 $(n=29)$ and Pinot Grigio-C $(n=29)$. ${ }^{\mathrm{x}}$ Within individual cultivar or frost protection treatment different letters indicate significant differences between means at $P<0.1$ level (Tukey's test). 
Table 2. Impact of cultivar (CV) and frost protection (FP) treatments on osmotic potential $\left(\Psi_{\mathrm{s}}\right)$ of leaf tissues.

\begin{tabular}{llcccc}
\hline & \multicolumn{5}{c}{ CV } \\
\cline { 2 - 6 } & Albariño & Cabernet Franc & Cabernet Sauvignon & Pinot Grigio & Mean \\
\cline { 2 - 6 } FP & & & $\Psi_{\mathrm{s}}(\mathrm{MPa})$ & -0.83 & $-0.77 \mathrm{a}^{\mathrm{x}}$ \\
$\mathrm{C}^{\mathrm{z}}$ & $-0.70^{\mathrm{y}}$ & -0.78 & -0.77 & -1.08 & $-0.92 \mathrm{~b}$ \\
KDL24 & -0.78 & -0.89 & -0.95 & -1.02 & $-0.86 \mathrm{~b}$ \\
KDL48 & -0.74 & -0.87 & -0.80 & $-0.98 \mathrm{c}$ & \\
Mean & $-0.74 \mathrm{a}$ & $-0.85 \mathrm{~b}$ & $-0.84 \mathrm{~b}$ & & \\
& & & & & \\
$P$ value CV & $<0.001$ & & & & \\
$P$ value FP & $<0.001$ & & & & \\
$P$ value CV $\times$ FP & 0.211 & & & & \\
\hline
\end{tabular}

${ }^{2}$ Frost protection treatments abbreviation: $\mathrm{C}=$ control; KDL24 $=\mathrm{KDL}$ sprayed $24 \mathrm{~h}$ before lowtemperature exposure; KDL48 $=$ KDL sprayed $48 \mathrm{~h}$ before low-temperature exposure.

${ }^{y}$ Values are averages of 20 cuttings.

${ }^{\mathrm{x}}$ Within individual cultivar or frost protection treatment different letters indicate significant differences between means at $P<0.1$ level (Tukey's test).

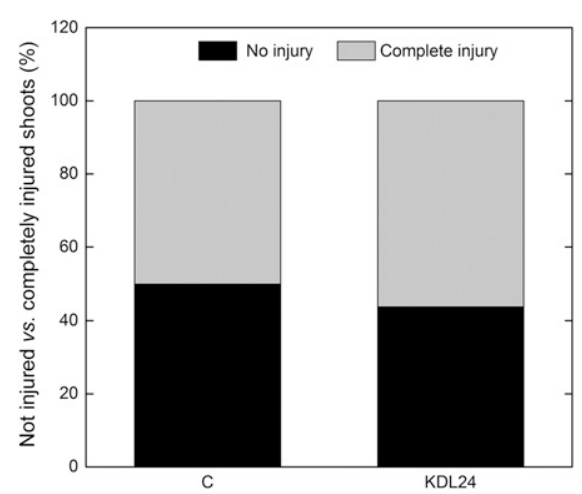

Fig. 1. Percentage of not injured (black bars) and completely injured (gray bar) 'Noiret' shoots after the controlled-freezing test. Treatments abbreviation: $\mathrm{C}=$ control; KDL24 $=$ KDL applied $24 \mathrm{~h}$ before low-temperature exposure. Total number of shoots analyzed for C and KDL24 treatments was 186 and 185 , respectively.

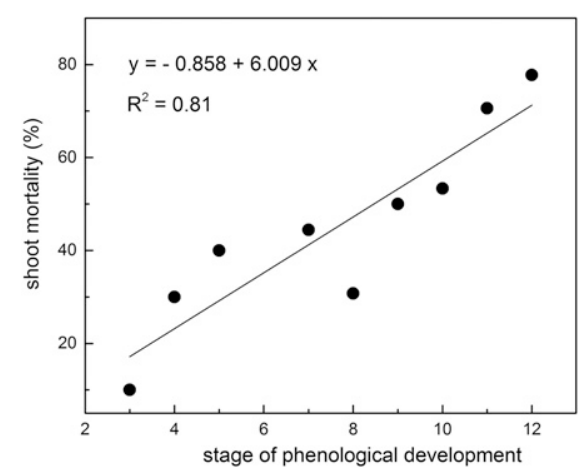

Fig. 2. Relation between incidence of shoot mortality (\%) and stage of phenological development (modified E-L system) for 'Noiret' control (C) vines. $\left(R^{2}=0.81 ; P<0.001\right)$. For each phenological stage the number of shoots analyzed was: stage $3(\mathrm{n}=40), 4(\mathrm{n}=15), 5(\mathrm{n}=$ 20), $7(\mathrm{n}=18), 8(\mathrm{n}=17), 9(\mathrm{n}=19), 10(\mathrm{n}=$ $15), 11(\mathrm{n}=27)$, and $12(\mathrm{n}=15)$.

often conducted under controlled conditions. The use of excised shoots under controlledfreezing conditions may increase frost resistance of plant tissues when compared with field observations or to freeze tests on whole plants (Neuner et al., 1997). Nevertheless, previous studies found that freeze injury data obtained with laboratory-based tests corresponded to those measured under natural conditions (Barranco et al., 2005; Larcher, 1985). Neuner et al. (1997) suggested that excised twigs/stems may have greater ability to supercool, and therefore greater freeze avoidance ability, than whole plants. This could be related to a decreased probability of active ice nuclei in samples of small size. In our study, to reduce the chance of supercooling and to be able to assess freeze survival, we sprayed plant material with distilled water before exposure to low temperature, as recommended by previous studies (Fuller et al., 2003; Johnson and Howell, 1981b; Pearce, 2001).

Shoot mortality varied significantly among the four $V$. vinifera cultivars tested. Previous research also indicated variability in spring frost resistance between cultivars of grapevine (Johnson and Howell, 1981b), as well as sweet cherry (Kappel, 2010), highbush blueberry (Rowland et al., 2013), and olive (Barranco et al., 2005) using either controlled-freezing tests or under natural conditions. To date, it is unclear what mechanism is behind the different level of freeze injury observed in different cultivars at the same stage of growth. Mechanisms suggested include differences in concentration and activity of ice nucleation-active bacteria or intrinsic ice nucleators which impact freezing temperature of plant tissues (Kappel, 2010). Moisture content, which is considered to increase freezing risk and reduce supercooling, may also vary among cultivars (Rodrigo, 2000). Finally, differences in leaf morphology and texture may account for differences in leaf ice nucleation when ice nucleation is caused by external ice (Fuller et al., 2003; Johnson and Howell, 1981a).

Single-bud cuttings were collected from grapevines exposed to the same environmental and growing conditions. Below average air temperatures were recorded at the vineyard site for the two winters prior the study $\left(T_{\min }=-19{ }^{\circ} \mathrm{C}\right.$, 7 Jan. $2014 ; T_{\min }=-17{ }^{\circ} \mathrm{C}$, 24 Feb. 2015). In the 2015 growing season, a lower than average number of shoots and clusters per vine were recorded for 'Albariño' in response to winter cold injury (unpublished data collected as part of the NE1020 project). No visual symptoms of winter cold injury were observed in 'Cabernet Franc', 'Cabernet Sauvignon', and 'Pinot Grigio'. Compromised health conditions of 'Albariño' vines may have contributed to lowered soluble carbohydrate concentrations resulting in higher susceptibility to postbudburst freeze injury compared with the other cultivars tested. Accumulation of intracellular water-soluble solutes, including sugars, can decrease $\Psi_{\mathrm{s}}$ and potentially cause freeze-induced dehydration of cell protoplasm (Sakai and Larcher, 1987). Osmotic potential for 'Albariño' was indeed the highest among the four cultivars tested. Sugars and other compounds such as lipids, soluble proteins, and free proline may also enhance membrane stability and preserve protein structure and function (Jacobsen et al., 2007).

Although cultivars may have different sensitivity to post-budburst freeze injury, differences in natural development rates could be more important than small changes in frost resistance, as suggested by Johnson and Howell (1981a). Early budburst cultivars could still be subjected to higher risk of spring freeze injury compared with those with later budburst. Our work supports previous studies on the increase of freeze injury with the advancement of bud/shoot development (Fuller and Telli, 1999; Gardea et al., 1993; Johnson and Howell, 1981a). However, while previous research only evaluated a few stages of phenological development, our study explored the extent of shoot mortality over a wide range of growth stages, varying from stage three to stage 12 . We found that shoot mortality in 'Noiret' vines increased from $10 \%$ when the buds were still dormant, but approaching budburst up to $78 \%$ when the shoots had five leaves separated. Higher water content in advanced compared with early stage of bud/shoot development may in part explain differences in freeze injury in response to phenological stage (Fuller and Telli, 1999).

Our results indicated that shoot mortality was, on average, $16 \%$ lower in KDL24treated shoots as compared with the $\mathrm{C}$ treatment. No impact on shoot mortality was observed when increasing the timing between KDL application and cold temperature exposure (24 and 48 h). Similarly, KDL sprayed $48 \mathrm{~h}$ before controlled-freezing test did not protect flowers of strawberry plants from freeze injury (Warmund and English, 1994). Future work could investigate if further reducing the time interval between KDL application and low-temperature exposure $(<24 \mathrm{~h})$ may increase the product efficacy. Nevertheless, KDL sprayed $24 \mathrm{~h}$ before lowtemperature exposure did not affect shoot mortality for 'Noiret' vines. Different vine species, experimental protocol, equipment used, as well as low temperatures tested $\left(-3.5\right.$ and $\left.-4{ }^{\circ} \mathrm{C}\right)$ prevent direct comparison of the outcomes of the two controlledfreezing tests. Since no extra 'Noiret' plant 
material was available for a freezing test on cuttings, we were unable to assess if using the same genotype in the two experimental systems (cuttings and whole vines) would have generated similar results. Therefore, we did not find a clear evidence of the efficacy of KDL as a cryoprotectant against postbudburst freeze injury. We recognize that the effectiveness of KDL may be greater under a natural frost event, different experimental protocols, or higher temperatures tested.

Although it has been suggested that changes in osmotic solutes may be correlated with frost resistance mechanisms (Levitt, 1980), there is no information available on how $\Psi_{\mathrm{s}}$ in leaf tissues relates to differences in post-budburst frost resistance. Only one study measured $\Psi_{\mathrm{s}}$ following applications of FP products (Wilson, 2001). Among the three treatments, the lowest $\Psi_{\mathrm{s}}$ was observed in the KDL24treated shoots, which translated to the lowest mortality of shoots assigned to this treatment. However, KDL48-treated shoots exhibited lower $\Psi_{\mathrm{s}}$ but similar shoot mortality as compared with the $\mathrm{C}$ shoots. It may be possible that the change in $\Psi_{\mathrm{s}}$ was too small to increase frost resistance of the tissue. Moreover, although KDL was applied a low concentration $(1 \% \mathrm{v} / \mathrm{v})$, we cannot preclude the possibility that residues of salt (i.e., potash) on the leaf surface affected osmolality values. Finally, induced protection mechanisms against freeze injury involve multiple factors, including osmotic, but also membrane protection mechanisms (Coughlan and Heber, 1982).

To shed light on the mode of action behind KDL, foliar application of the brown seaweed ingredient $A$. nodosum should be tested. A. thaliana plants exhibited increased cold temperature resistance when irrigated with an A. nodosum extract (Rayirath et al., 2009). Furthermore, A. thaliana plants treated with the seaweed extract showed a greater freezing recovery as compared with untreated plants. Rayirath et al. (2009) suggested that chemical components in $A$. nodosum extracts protected cell membrane integrity and affected the expression of genes involved with stress response, including frost resistance. However, it is not clear if foliar application could result in a similar plant response. We suggest that future studies should consider foliar seaweed extract application rather than irrigation due to its practical relevance.

Frost protection of grapevine following budburst is a major concern for grapevine producers, particularly in light of changing climatic conditions and a projected increase in unpredictable weather patterns like early spring warming and late spring frosts (Mosedale et al., 2015). Planting late bursting cultivars still appears to be a more reliable method for avoiding spring frost injury as compared with the use of cryoprotectant products.

\section{Literature Cited}

Agro-K Corporation. 2014. Get a jump on frost with KDL. Agro-K Corporation, Minneapolis 12 Apr. 2016. <http://www.agro-k.com/wpcontent/uploads/2014/08/kdl-frost-flyer.pdf $>$.

Agro-K Corporation. 2016. Agro-K Corporation, Minneapolis. 12 Apr. 2016.<http://agro-k.com/>.

Anderson, J.A. and J. Whitworth. 1993. Supercooling strawberry plants inoculated with icenucleation active bacteria and treated with frostgard. HortScience 28:828-830.

Barranco, D., N. Ruiz, and M. Gómez-del Campo. 2005. Frost tolerance of eight olive cultivars. HortScience 40:558-560.

Burns, R.M. 1973. Chemical sprays for protection of young trees. Citrograph 59:7-8.

Coombe, B.G. 1995. Adoption of a system for identifying grapevine growth stages. Austral. J. Grape Wine Res. 1:104-110.

Coughlan, S. and U. Heber. 1982. The role of glycine betaine in the protection of spinach thylakoids against freezing stress. Planta 156:62-69.

Evans, R.G. 2000. The Art of Protecting Grapevines from Low Temperature Injury. Proc. ASEV 50th Anniversary Annu. Mtg., Seattle, 19-23 June. p. 60-72.

Fuller, M.P., F. Hamed, M. Wisniewski, and D.M. Glenn. 2003. Protection of plants from frost using hydrophobic particle film and acrylic polymer. Ann. Appl. Biol. 143:93-97.

Fuller, M.P. and G. Telli. 1999. An investigation of the frost hardiness of grapevine (Vitis vinifera $\mathrm{L}$.) during budbreak. Ann. Appl. Biol. 135:589-595.

Gardea, A.A., P.B. Lombard, C.H. Crisosto, L.W Moore, L.H. Fuchigami, and L.V. Gusta. 1993. Evaluation of frostgard as an antifreeze, inhibitor of ice nucleators, and cryoprotectant on Pinot noir leaf tissue. Amer. J. Enol. Viticult. 44:232-235.

Himelrick, D.G., R.M. Pool, and P.J. McInnis. 1991. Cryoprotectants influence freezing resistance of grapevine bud and leaf tissue. HortScience 26:406-407.

Imani, A., K. Barzegar, and S. Pirireivatlou. 2011. Relationship between frost injury and ion leakage as an indicator of cold hardiness in 60 almond selections. Intl. J. Nutr. Relat. Sci. 2(1):22-26.

Jacobsen, S.E., C. Monteros, L.J. Corcuera, L.A Bravo, J.L. Christiansen, and A. Mujica. 2007. Frost resistance mechanisms in quinoa (Chenopodium quinoa Willd.). Eur. J. Agron. 26:471-475.

Johnson, D.E. and G.S. Howell. 1981a. The effect of cane morphology and cultivar on the phenological development and critical temperatures of primary buds on grape canes. J. Amer. Soc. Hort. Sci. 106:545-549.

Johnson, D.E. and G.S. Howell. 1981b. Factors influencing critical temperatures for spring freeze damage to developing primary shoots on Concord grapevines. Amer. J. Enol. Viticult. 32(2):144-149.

Kappel, F. 2010. Sweet cherry cultivars vary in their susceptibility to spring frosts. HortScience 45:176-177.

Keller, M. 2010. The science of grapevines: Anatomy and physiology. 1st ed. Academic Press, Waltham, MA.

Larcher, W. 1985. Kglte und Frost, p. 107-320. In: P. Sorauer (ed.). Handbuch der Pflanzenkrankheiten. Verlag Paul Parey, Berlin, Germany.

Levitt, J. 1980. Responses of plants to environmental stresses, Vol. 1. 2nd ed. Academic Press, New York, NY.

Marini, R.P. 1999. Are nonsignificant differences really not significant? HortScience 34:761-762.

Matta, F.B., S. Little, and R.H. Mullenax. 1987. Effects of two chemicals on peach fruit survival following late spring frosts. Miss. Agr. For. Expt. Sta Res. Rpt. 12(18).
Molitor, D., A. Caffarra, P. Sinigoj, I. Pertot, L. Hoffmann, and J. Junk. 2013. Late frost damage risk for viticulture under future climate conditions: A case study for the Luxembourgish winegrowing region. Austral. J. Grape Wine Res. 20:160-168.

Mosedale, J.R., R.J. Wilson, and I.M.D. Maclean. 2015. Climate change and crop exposure to adverse weather: Changes to frost risk and grapevine flowering conditions. PLoS One 10: e0141218.

Neuner, G., P. Bannister, and W. Larcher. 1997. Ice formation and foliar frost resistance in attached and excised shoots from seedlings and adult trees of Nothofagus menziesii. N.Z. J. Bot. 35:221-227.

Nuccio, M., B. Russell, K. Nolte, B. Rathinasabapathi, D. Gage, and A. Hanson. 1998. The endogenous choline supply limits glycine betaine synthesis in transgenic tobacco expressing choline monooxygenase. Plant J. 16:487-496.

Pearce, R.S. 2001. Plant freezing and damage. Ann. Bot. 87:417-424.

Perry, K.B., A.R. Bonanno, and D.W. Monks. 1992. Two putative cryoprotectants do not provide frost and freeze protection in tomato and pepper. HortScience 27:26-27.

Rayirath, P., B. Benkel, D.M. Hodges, P. AllanWojtas, S. Mackinnon, A.T. Critchley, and B. Prithiviraj. 2009. Lipophilic components of the brown seaweed, Ascophyllum nodosum, enhance freezing tolerance in Arabidopsis thaliana. Planta 230(1):135-147.

Rodrigo, J. 2000. Spring frosts in deciduous fruit trees-Morphological damage and flower hardiness. Scientia Hort. 85:155-173.

Rowland, L.J., E.L. Ogden, F. Takeda, D.M Glenn, M.K. Ehlenfeldt, and B.T. Vinyard. 2013. Variation among highbush blueberry cultivars for frost tolerance of open flowers. HortScience 48:692-695.

Sakai, A. and W. Larcher. 1987. Frost survival of plants: Responses and adaptation to freezing stress (Ecological studies). Springer, Berlin, Germany.

Snyder, R.L. and J.P. de Melo-Abreu. 2005. Frost protection: Fundamentals, practice, and economics. 23 Nov. 2015. <http://www.fao.org/ docrep/008/y7223e/y7223e00.HTM>.

Trought, M.C.T., G.S. Howell, and N. Cherry. 1999. Practical considerations for reducing frost damage in vineyards. Rpt. N.Z. Winegrowers. 23 Nov. 2015. <http://www.nzwine.com/assets/sm/ upload/eb/fl/ot/sp/frost_review.pdf $>$.

Turner, N. 1981. Techniques and experimental approaches for the measurement of plant water status. Plant Soil 58:339-366.

Warmund, M.D. and J.T. English. 1994. Efficacies of cryoprotectants applied to 'Honeoye' strawberry plants inoculated with ice-nucleationactive bacteria. Adv. Strawberry Res. 13:20-25.

Warmund, M.R., P. Guinan, and G. Fernandez. 2008. Temperatures and cold damage to small fruit crops across the eastern United States associated with the April 2007 freeze. HortScience 43:1643-1647.

Wilson, S. 2001. Frost management in cool climate vineyards. Final report to Grape and Wine Research \& Development Corporation. 25 Nov. 2015. <http://www.gwrdc.com.au/wp-content/ uploads/2012/09/UT-99-1.pdfs.

Wolf, T.K. 2008. Wine grape production guide for eastern North America. Natural Resource, Agriculture, and Engineering Service, Ithaca, NY.

Xing, W. and C.B. Rajashekar. 2001. Glycine betaine involvement in freezing tolerance and water stress in Arabidopsis thaliana. Environ. Expt. Bot. 46:21-28. 